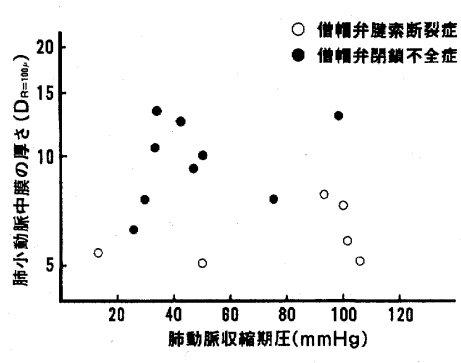

図 3 肺小動脈中膜厚之肺動脈収縮期圧は 無相関であった

\section{考察}

僧帽弁腱索断裂症では僧帽弁閉鎖不全症に比べ肺小動 脈, 肺静脈とむに中膜肥厚が少なく内膜病変が高度で あった，乙の原因について，僧帽台閉鎖不全症では肺小 動脈之肺静脈の中膜が肥厚して静脈性の肺高血圧に適応 するが，僧帽弁腱索断裂症では静脈性の肺高血圧が突発 的に発症するため肺血管床がすぐには反応できず中膜肥 厚が遅れ高度の縦走平滑筋細胞の増殖を招くと推測され
た、しかし，との病変が初期の変化であるかどうかはい まのところ不明である。

通常，先天性心疾患儿伴う肺高血圧症では肺動脈圧の 上昇にしたがって肺小動脈中膜が肥厚することが指摘さ れている ${ }^{1,22}$ （しかし，僧帽弁腱索断裂症，僧帽弁閉銧 不全症と屯に肺動脈圧之肺小動脈中膜厚との間に相関関 係がみられなかった，一方，肺小動脈中膜厚と血管内腔 狭窄度とを求め肺血管病変の総和として肺動脈圧と比較

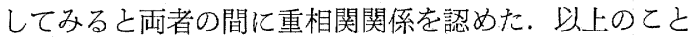
は肺動脈圧は肺小動脈中膜厚と血管内腔狭窄度の総和に より規定されることを示唆する．すなわち，肺動脈圧の 上昇に伴い肺小動脈中膜が肥厚し，次の段階で内膜病変 が出現する先天性心疾患 ${ }^{3,4)}$ ，之は肺血管病変の発生機序 が異なり, 内膜病変が早期より発生することが推測され た.

文 献 1) Yamaki, S. et a1.: Circulation 54: 805, 1976. 2) Yamaki, S. et a1.: Am. J. Cardiol. 51: 1502, 1983. 3) Yamaki, S. et al.: Am. J. Cardio1. 44: 284, 1979. 4) Yamaki, S. et al.: Am. J. Pathol. 105: 70, 1981.

\title{
192 心臓再手術の術中副損傷の検討
}

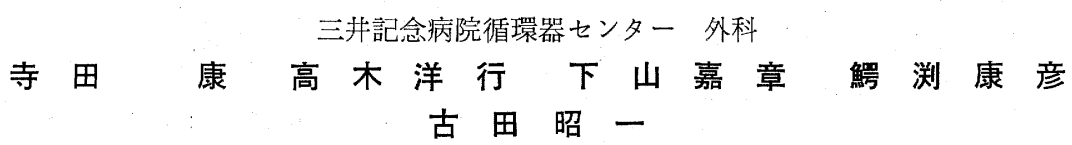

心臟弁膜症の再手術は，安全に心臟に到達するまでに 心囊内痖着剝離を行わなければならず，そこに初回手術 にはない副損傷の危険を伴う。また，副損傷の有無，程 度が手術成績に及ぼす影響む大である，そてで，心臟弁 膜症再手術の際の副損傷につい調べたので報告する.

\section{対象}

平成元年 5 月 31 日までに, 三井記念病院循環器外科 で, reds median sternotomy で心臟再手術を施行した 123 例中, 術中に止血操作を必要とする副損傷を起こし た 33 例 (26.8\%) を対象とした.

症例の内訳は, 男 12 例, 女 21 例, 手術時年歯位 $3 \sim$ 73 歳 (平均 43.2 歳) であった. 術前の NYHA 心機能 分類は, II度 7 例, III度 18 例, IV度 8 例で, 再手術の
緊急度では，待期手術が 25 例，準緊急手術 5 例，緊急 手術が 3 例であった。

\section{結果}

前回の手術部位と今回の再手術の部位を表 1 亿まとめ た．前回手術部位では，大動脈弁之僧帽弁，僧帽弁と三 尖弁之，二弁に手術を行った症例が 6 例ずつ，計 12 例 (36.4\%) であった．また，再手術では，9例（27.3\%) が二弁に，しかもそのうち8例が三尖弁の手術を必要之 した.

再手術の回数では，1回目の再手術が 29 例，2 回目 が 2 例, 3 回目が 2 例であった.

術中,副損傷の部位と起とった時間を表 2 にまとめた。 Reds sternotomy 前の胸骨離面を剝離中の右房損傷が 
表 1 前回手術部位と再手術部位

\begin{tabular}{lcc}
\hline & 前回手術 & 再手術 \\
\hline 大動脈弁 & 1 & 1 \\
僧帽弁 & 20 & 23 \\
大動脈弁十僧帽弁 & 6 & 1 \\
僧帽弁十三尖弁 & 6 & 8 \\
\hline
\end{tabular}

1 例, redo sternotomy の際の損傷が計 11 例（右房 7 例，右室 2 例，大動脈，肺がそれぞれ 1 例）あった。さ らに rodo sternotomy 後, 開胸器で胸骨を開ける際の 無名静脈の損傷，断裂が 3 例，右室の裂傷が 1 例，開胸 器の鉤による右室の損傷が 1 例あった．癒着剝離中の損 傷は計 27 例で，そのうち 22 例 $(81.4 \%)$ が右心系で あった。 この中で 9 例は副損傷後ただちに体外循環を開 始したが，4例は出血性ショックに陥った．無名静脈を 損傷した 2 例，大動脈を損傷した 1 例は，副損傷による 出血が原因で死亡した。

術中に副損傷を起こした 33 例中 19 例 (57.6\%) に 術後合併症を認め， 7 例（21.2\%）が一度屯退院できず 死亡した. 合併症の内訳を表 3 亿示したが, 出血が 7 例, 感染が計 6 例, LOS から多藏器不全への移行が 4 例，脳梗塞，術後痤攣が 1 例ずつであった.

\section{考察および結論}

心臟弁膜症の術後遠隔期生存例驾増加するにつれて， 心臟再手術例増加しつつある．とくに当院では 1977 年以降，僧帽弁置換術には一貫して生体弁を第一選択と してきたが，長期間の遠隔期成績においては，その耐久 性が大きな問題となりつづり，僧帽弁位生体弁の人工 弁機能不全の非発生率は，5年で $96 \% ， 8$ 年で $81 \%$, 10 年で $64 \%$ であり ${ }^{1)}$, 最近の再弁置換術増加の一因々 なっていると考えられた，以上のように，生体弁を第一 選択としてきた施設にとって，再手術を安全に行うこと は必要の条件である.
表 3 合 併 症

\begin{tabular}{|c|c|c|}
\hline \multicolumn{2}{|c|}{ 術中術後出血 } & 7 (3) 例 \\
\hline \multirow{3}{*}{ 感 染 } & (縦 隔 炎 & 2 \\
\hline & $\{$ 創 感 染 & 1 \\
\hline & 敗 血 症 & $3(2)$ \\
\hline \multicolumn{2}{|c|}{$\mathrm{LOS} \rightarrow \mathrm{MOF}$} & $4(1)$ \\
\hline \multicolumn{2}{|c|}{ 脳 梗 塞 } & 1 \\
\hline \multirow[t]{2}{*}{ 痤 } & 挙 & $1(1)$ \\
\hline & & 19 (7) 例 \\
\hline
\end{tabular}

Redo sternotomy の際の出血は, 死亡の原因之なり うるきわめて重篤な合併症である ${ }^{2 y}$ ，ᄂかし，ある頻度 の発生は避けられず，文献中の報告では 2 6\% であ $り^{3-5)}$, 当院の 123 例中 11 例 (8.9\%) はやや高い. 最 近では, redo sternotomy には, 振動型の saw を使用 しており，今後は技術の向上と細心の注意で redo sternotomy の際の副損傷は減少するととが期待される.

瘾着剝離の範囲は，とくに僧帽弁位の再手術では良好 な心臟内の視野を得るとともに，空気抜き，心筋保護の 点からあ可及的に十分剝離するととに心掛けている6゙. その際，慎重な永離操作で避けられる副損傷もある．と くに開胸器で胸骨を開ける際の無名静脈, 右室の断裂, 裂傷は意外に止血しにくく, 開胸器を掛ける前に胸骨離 面を十分に剶離することが大切である.

心臟再手術の際の副損傷の有無，程度が手術成績に及

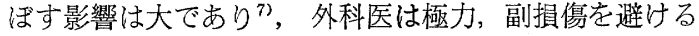
よう，努力が必要である。

文 献 1) 下山嘉章ほ加：人工臟器 18: 790, 1989, 2) Dobell, A. R. C. et al.: Ann. Thorac. Surg. 17: 157, 1984. 3) Husebye, D. G. et al.: J. Thorac. Cardiovasc. Surg. 86: 543, 1983. 4) Wideman, F.E. et al.: J. Thorac. Cardiovasc. Surg. 82: 692, 1981. 5) Rassiter, S. J. et al.: Arch. Surg. 114：1279，1979. 6) 寺田 康ほ加：手術(投稿中)。 7) 寺田 康ほ加：胸部外科 42：426, 1989 。

表 2 副損傷の部位と起とった時間

\begin{tabular}{|c|c|c|c|c|}
\hline & $\begin{array}{l}\text { Redo sternotomy } \\
\text { 前胸骨離面渌離中 }\end{array}$ & Redo sternotomy & $\begin{array}{l}\text { Sternal splitting } \\
\text { のとき }\end{array}$ & 䄖着剝離中 \\
\hline 無名静脈 & & & $3[2]$ & \\
\hline & $1(1)$ & $7(3)$ & & $12(2)$ \\
\hline 右室 & & 2 & $2(1)$ & 5 \\
\hline 上大静眽 & & & & 3 \\
\hline 下大静脈 & & & & 2 \\
\hline 右冠動脈 & & & & \\
\hline 大 動 脈 & & $1(1)$ & & $2(1)[1]$ \\
\hline 左 肺 ${ }^{\text {房 }}$ & & 1 & & 1 \\
\hline
\end{tabular}

（）：損傷後ただちに体外循環を使用した症例，〔 〕：副損傷の出血が原因の死亡例 